\title{
Interventional Bronchoscopic Approach to Emergent/Urgent Situations in the Era of Covid-19
}

\author{
(1) Efsun Gonca Ugur Chousein, (1) Mehmet Akif Ozgul, (1) Demet Turan, \\ (1) Ekrem Seyhan, (1) Erdogan Cetinkaya
}

Department of Pulmonology, University of Health Sciences Yedikule Chest Diseases and Thoracic Surgery Training and Research Hospital, istanbul, Turkey,

Submitted: 17.04.2021 Accepted: 08.06.2021

Correspondence: Efsun Gonca Ugur Chousein SBÜ Yedikule Göğüs Hastalıkları ve Göğüs Cerrahisi Eğitim ve Araştırma Hastanesi, Göğüs Hastalıkları Bölümü, İstanbul, Turkey E-mail: efsungoncachousein@gmail.com

口pras

Keywords: Covid-19; emergent; interventional pulmonology.

\begin{abstract}
Objective: The Covid-1 9 pandemic has caused delays in elective medical and surgical procedures in accordance with the measures and precautions to be taken. Alternative, low transmission risk procedures had to be adopted. Urgent and emergent interventional bronchoscopic procedures (IBP) were continued to be performed in life-threatening conditions. We aimed to evaluate the IBP performed during the ongoing pandemic in terms of patient selection, diagnoses, emergency/urgency, type of procedure used, success, and complications.
\end{abstract}

Methods: Patients who underwent IBP in the first wave of pandemic between March II, 2020, when the first patient was diagnosed with Covid-19, and June I, 2020, in Turkey.

Results: Twenty-one patients with a mean age of $54.7 \pm 17$ years underwent 23 emergent/ urgent IBP. Nine patients had malignant and 9 had benign airway obstruction. The remaining 3 patients were diagnosed with hemoptysis and pulmonary alveolar proteinosis. The success rate of IBP treatment was $100 \%$, the acute complication rate was $4.7 \%$, the chronic complication rate was $4.7 \%$, the procedural mortality was $0.0 \%$ and the 30 -days early mortality rate was $9 \%$. All procedures were performed in interventional pulmonology (IP) unit with negative room pressure with as few auxiliary staff as possible. None of our team members developed signs and symptoms of coronavirus disease with the contribution of the constantly updated literature to our increasing clinical experience and measures taken.

Conclusion: IBP can be performed with high success and low complication rates, even under pandemic conditions, especially in emergent/urgent life-threatening situations such as central airway obstructions, massive hemoptysis, and other diseases, in the absence of other surgical and invasive procedures. They have a life-saving, survival-prolonging and time-saving role up to primary therapy, provided that all necessary precautions are taken.

\section{INTRODUCTION}

SARS-Cov-2 (the cause of Covid-19) has spread globally causing a pandemic with recurrent peaks with a primary mode of transmission via droplets. ${ }^{[1-3]}$ Therefore, endoscopic procedures such as bronchoscopy are defined as high-risk procedures. Guidelines suggested postponing non-urgent elective procedures or considering alternative methods with less transmission risk ${ }^{[4,5]}$ in cases presenting to emergency care with central airway obstructions (CAO) caused by tumors, postintubation stenosis (PITS), foreign body aspiration (FBA) or massive hemoptysis with respiratory distress. ${ }^{[4]}$

IBP is life-saving, survival-prolonging, and time-saving for these patients, and performing the procedure by taking optimal precautions during the pandemic is important for both the patient and the interventional pulmonology (IP) team. ${ }^{[6-8]}$

It is aimed to evaluate the success and complications of IBP that could not be postponed because of emergent/ urgent situations.

\section{MATERIALS AND METHODS}

\section{Study population}

A total of 21 patients who underwent IBP in the IP unit, from March II, 2020, to June I, 2020, during the first peak of the pandemic were retrospectively evaluated in terms of demographic data, diagnoses, swab-PCR results, bronchoscopic findings, and modalities used and their complications. 
The study was approved by the ethics committees of the University of Health Sciences of Turkey (46418926050.03.04: 20/201), and the Turkish Ministry of Health (2020-05-29T08_17_44), and carried out in accordance with the Declaration of Helsinki. Written consent was obtained from all patients at the time of hospitalization according to the general practice of our hospital.

\section{Interventional bronchoscopic procedures}

The procedures were performed under general anesthesia (GA). All patients were monitored with electrocardiography and $\mathrm{SpO}_{2}$ during the procedure, and arterial blood pressure measured every 5 minutes. GA induction was achieved with midazolam $0.05-0.10 \mathrm{mg} / \mathrm{kg}$, diprivan, remifentanil (maximum dose $2 \mathrm{mg}$ ), and rocuronium (maximum dose $50 \mathrm{mg}$ ). The equipment used in the procedures included the Dumon Series II rigid bronchoscopes (Efer Endoscopy, La Ciotat, France). Argon Plasma Coagulation (APC) (40 W, blended mode/continuous flow) was applied using an instrument by ERBE Elektromedizin $\mathrm{GmbH}$ (Tubingen, Germany). A diode laser operating at a wavelength of $980 \mathrm{~nm}$ with 4 to $25 \mathrm{~W}$ in pulsed mode (Biolitec Ceralas D25; Germany) and a cryo-probe of ERBOKRYO system (Elektromedizin GmbH, Tubingen, Germany) were used. Patients were classified as emergent, urgent and non-urgent cases according to the American Association for Bronchology and Interventional Pulmonology (AABIP) Statement 2020. Emergent cases were defined as moderate-to-severe tracheal or bronchial stenosis, symptomatic $\mathrm{CAO}$, massive hemoptysis, or migrated stents. These cases underwent emergent IBP after completing their initial emergent evaluation. Urgent cases were lung mass or mediastinal/hilar lymphadenopathy suspected for cancer, FBA, pulmonary alveolar proteinosis (PAP) indicating whole lung lavage (WLL). These patients were hospitalized/treated in our outpatient clinics, provided that initial preparations were made so that they could undergo IBP immediately when they deteriorated.

\section{Statistical analysis}

Statistical analysis was performed using the SPSS 16 software(SPSS, Inc., Chicago, IL, USA). All categorical variables are presented as counts and percentages. Variables are presented as means with standard deviation, continuous variables as median and range.

\section{RESULTS}

Twenty-one patients (mean age $54.7 \pm 17$ years, $61.9 \%$ male) underwent 23 IBPs. The most common presenting complaints were dyspnea/stridor (7I.4\%) (Table I). Oxygen saturation in room air was $<90 \%$ in all of them, of which $5(23.8 \%)$ were emergent and the rest were urgent (Table 2).

Pre-treatment swab-PCR results were not available in 6 patients and the remaining 15 had negative results (Table 2).
Table I. Demographic, and clinical details of the study population $(n=2 I)$

\begin{tabular}{|c|c|}
\hline Variables & Value \\
\hline Age, years (mean $\pm S D)$ & $54.7 \pm 17$ \\
\hline Gender (male), n (\%) & $13(61.9)$ \\
\hline \multicolumn{2}{|l|}{ Comorbidities, n (\%) } \\
\hline Diabetes mellitus & $4(19)$ \\
\hline Cardiovascular disease & $5(23.8)$ \\
\hline Cerebrovascular disease & $5(23.8)$ \\
\hline Chronic pulmonary disease & $4(19)$ \\
\hline Others* & $8(38)$ \\
\hline \multicolumn{2}{|l|}{ Symptoms, n (\%) } \\
\hline Dyspnea/stridor & $15(7 \mid .4)$ \\
\hline Hemoptysis & $2(9.5)$ \\
\hline Both & $4(19)$ \\
\hline Group I: Malignant airway obstruction, n (\%) & $9(42.8)$ \\
\hline Primary pulmonary malignancy & $6(28.5)$ \\
\hline Squamous cell carcinoma & $3(14.2)$ \\
\hline Small cell lung carcinoma & $2(9.5)$ \\
\hline Adenocarcinoma & I (4.7) \\
\hline Secondary pulmonary malignancy & $3(14.2)$ \\
\hline Thyroid carcinoma & I (4.7) \\
\hline Breast carcinoma & I (4.7) \\
\hline Renal cell carcinoma & I (4.7) \\
\hline Group 2: Benign airway obstruction, n (\%) & $9(42.8)$ \\
\hline Postintubation/tracheostomy tracheal stenosis & $7(33.3)$ \\
\hline Foreign body aspiration & $2(9.5)$ \\
\hline Group 3: Miscellaneous, n (\%) & $3(14.2)$ \\
\hline Hemoptysis & $2(9.5)$ \\
\hline Pulmonary alveolar proteinosis & I (4.7) \\
\hline \multicolumn{2}{|l|}{ Locations of the obstructions, $n,(\%)$} \\
\hline Trachea & $5(23.8)$ \\
\hline $\begin{array}{l}\text { Right bronchial system ( } 3 \text { main bronchus, } \\
\text { I lower lobe bronchus) }\end{array}$ & $4(19)$ \\
\hline Left bronchial system ( 3 main bronchus) & $3(14.2)$ \\
\hline
\end{tabular}

SD: Standard deviation, $\mathrm{n}$ : Number; *: Other comorbidities: [carcinoma $(n=5)$, pulmonary thromboembolism $(n=1)$, benign prostate hyperthrophy $(n=1)$, tuberculosis sequela $(n=1)]$.

They had an American Society of Anaesthesiologists Physical Status Classification System (ASA) mean score of 4. $I \pm 0.35$. The mean number of procedures performed per patient was $I \pm 0.3$, and the median procedure time was 45 (30-59) minutes (Table 2). Patients were categorized into 3 groups according to their primary conditions as follows:

Group I [Malignant airway obstructions (MAO)]

Group 2 [Benign airway obstructions (BAO)]

Group 3 [Miscellaneous (including hemoptysis and respiratory failure due to PAP)].

The MAO group consisted of 9 patients, 6 of whom were due to primary and 3 due to secondary pulmonary malignancies, while the BAO group consisted of 7 patients with PITS and 2 with FBA. There were also 3 patients; 2 
Table 2. Characteristics of the patients according to groups

\begin{tabular}{|c|c|c|c|c|}
\hline & Total $(n=2 I)$ & Group I $(n=9)$ & Group $2(n=9)$ & Group $3(n=3)$ \\
\hline Age (years) (mean $\pm S D)$ & $54.7 \pm 17$ & $58 \pm 20.76$ & $52 \pm 15.6$ & $5 I \pm I .53$ \\
\hline Gender (male), n (\%) & $13(6 \mid .9)$ & $4(44.4)$ & $6(66.6)$ & $3(100)$ \\
\hline ASA (mean $\pm S D)$ & $4.1 \pm 0.35$ & $4.1 \pm 0.33$ & $4.1 \pm 0.33$ & $4.3 \pm 0.57$ \\
\hline Emergent patient number, $\mathrm{n}(\%)$ & $5(23.8)$ & $2(22.2)$ & $3(33.3)$ & $0(0.0)$ \\
\hline Comorbidities, n (\%) & $13(6 \mid .9)$ & $6(66.6)$ & $6(66.6)$ & I (33.3) \\
\hline Mean percentage of lumen obstruction (\%) & $84.75 \pm 11.90$ & $86 \pm 14.08$ & $82.8 \pm 9.06$ & - \\
\hline Duration of procedure (minute) & $45(30-52)$ & $50(37.5-59)$ & $40(30-68)$ & $45(40-161)$ \\
\hline Follow-up duration (days) & $55(44-87.5)$ & 47 (44.5-99) & $67(37.5-89)$ & $45(4-53)$ \\
\hline Procedure, n (\%) & & 9 & 9 & 3 \\
\hline Argon plasma coagulation & $10(47.6)$ & 7 (77.7) & $2(22.2)$ & I (33.3) \\
\hline Mechanical dilation & $10(47.6)$ & $3(33.3)$ & 7 (77.7) & $0(0.0)$ \\
\hline Mechanical resection & $9(42.8)$ & $5(55.5)$ & $3(33.3)$ & I (33.3) \\
\hline Stenting & $6(28.5)$ & $4(44.4)$ & $2(22.2)$ & $0(0.0)$ \\
\hline Scissors & $2(9.5)$ & $0(0.0)$ & $2(22.2)$ & $0(0.0)$ \\
\hline Cryo & I (4.7) & $0(0.0)$ & I (II.I) & $0(0.0)$ \\
\hline Acute complication, n, (\%) & I (4.7) & $0(0.0)$ & I (II.I) & $0(0.0)$ \\
\hline Hemorrhage & I (4.7) & $0(0.0)$ & I (II.I) & $0(0.0)$ \\
\hline Atrial fibrillation & $0(0.0)$ & $0(0.0)$ & $0(0.0)$ & $0(0.0)$ \\
\hline Respiratory failure requiring mechanical ventilation & $0(0.0)$ & $0(0.0)$ & $0(0.0)$ & $0(0.0)$ \\
\hline Chronic complication, n, (\%) & I (4.7) & $0(0.0)$ & I (II.I) & $0(0.0)$ \\
\hline Granulation formation & I (4.7) & $0(0.0)$ & I (II.I) & $0(0.0)$ \\
\hline 30-days early mortality, n, (\%) & $2(9)$ & I (II.I) & $0(0.0)$ & I (II.I) \\
\hline Covid-19 swab-PCR results $n,(\%)$ & I5 (7I.4) & $6(66.6)$ & $6(66.6)$ & $3(100)$ \\
\hline Negative & $15(7 \mid .4)$ & $6(66.6)$ & $6(66.6)$ & $3(100)$ \\
\hline Positive & $0(0.0)$ & $0(0.0)$ & $0(0.0)$ & $0(0.0)$ \\
\hline Not availlable & $6(28.5)$ & $3(33.3)$ & $3(33.3)$ & $0(0.0)$ \\
\hline
\end{tabular}

SD: Standard deviation; n: Number; PCR: Polymerase chain reaction, Group I: Malignant airway obstruction group; Group 2: Benign airway obstruction group; Group 3: Miscellaneous group.

with hemoptysis and one with PAP. The mean ages of the groups were $58 \pm 20.7,52 \pm I 5.6$ and $5 I \pm I I .53$ years respectively (Table 2).

Six of the 9 patients treated for MAO had a primary lung malignancy. 3 (50\%) had squamous cell carcinoma, 2 (33.3\%) SCLC, and I (I6.6\%) adenocarcinoma. In 3 patients, secondary pulmonary malignancies due to thyroid, breast and kidney tumors were detected. Bronchoscopic findings were mixed type lesions in 5 patients, endoluminal lesion in 2, external compression in I, and mucosal/ submucosal infiltration in I. The mean obstruction degree in the MAO group was $86 \pm 14.08 \%$ at a mean distance of $2 \pm 0.6 \mathrm{l} \mathrm{cm}$ from the vocal cords, with a length of $2.1 \pm 0.54$ (Fig. Ia-f). Obstruction was most commonly detected in the trachea (Table I). Five of the MAO group were operable according to the tumour grading system, the remaining patients were inoperable.

Seven of the 9 BAO patients had PITS, one of whom had recently developed PITS after being successfully treated for Covid-19 pneumonia (CP) in an intensive care unit (ICU) (Fig. 2a-f), 2 with FBA (Fig. 3). Among patients with PITS, there were $5(85 \%)$ patients with complex type tracheal stenosis (CTTS) with a length of I.5 \pm 0.40 $\mathrm{cm}$ at a distance of $2 \pm 0.78 \mathrm{~cm}$ from the vocal cords, and stenosis degree was $82 \pm 9.06 \%$. Three patients with PITS presented with the migration of tracheal stents, the airway stents (AS) were pulled back to the original insertion site and sutured to the tracheal wall at 2 (as seen in Fig. 2a-f). Two patients had FBA (peanut and chicken meat) (Fig. 3a-d).

The most frequently used IBP were APC in 10 (47.4\%) patients, mechanical dilation in 10 (47.4\%), mechanical resection in $9(42.8 \%)$ and stenting in $6(28.5 \%)$. Airway stents (AS) were placed for both malignant and BAOs. 6 AS were implanted to 6 patients (4 in MAO, 2 in BAO); two were straight, 2 were hourglass and 2 were $y$-shaped. Two of these were semi-covered metallic stents and the rest were silicon. While 3 patients were treated due to complications related to their old AS, no acute complications due to the newly placed AS were observed.

Our procedural success rate was 100\%, our acute complication rate was $4.7 \%$ (I patient had a moderate hemorrhage and was easily controlled). The only chronic complication was the development of granulation tissue after 3 weeks which required a second revision (4.7\%). No patient died during the procedures. One patient with MAO died 

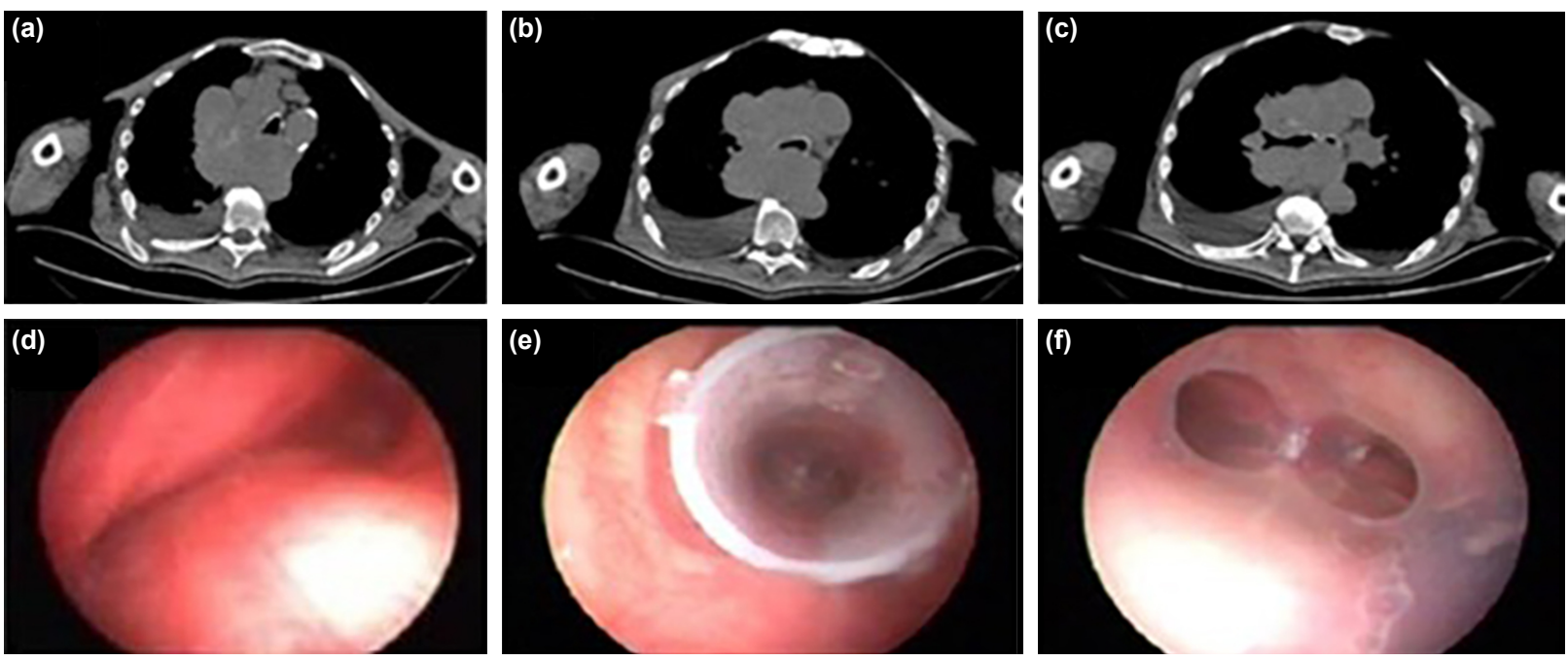

Figure 1. Malignant airway obstruction due to small cell lung cancer. (a-c) Computed tomography sections showing external compression of small cell lung cancer in the distal part of the trachea and main bronchi. (d-f) Bronchoscopic view of external compression in the airways and Y-shaped silicone stent after the implantation.
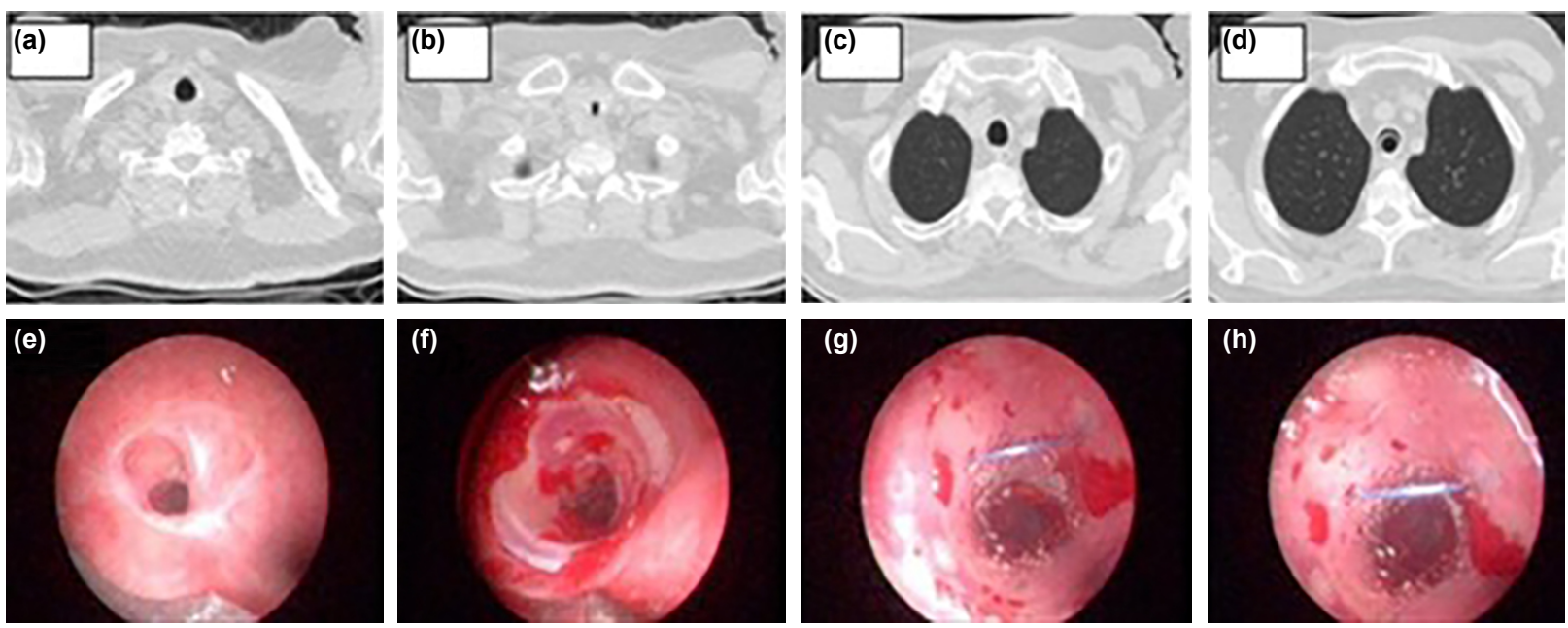

Figure 2. Benign airway obstruction (Postintubation tracheal stenosis) and migration of the stent. (a-d) Computed tomography sections of the stenotic part of the trachea and migrated stenotic stent beyond the stenotic part. (e-h) Rigid bronchoscopic view of the stenotic part of the trachea and suture fixation of the stent in order to prevent recurrence of migration.
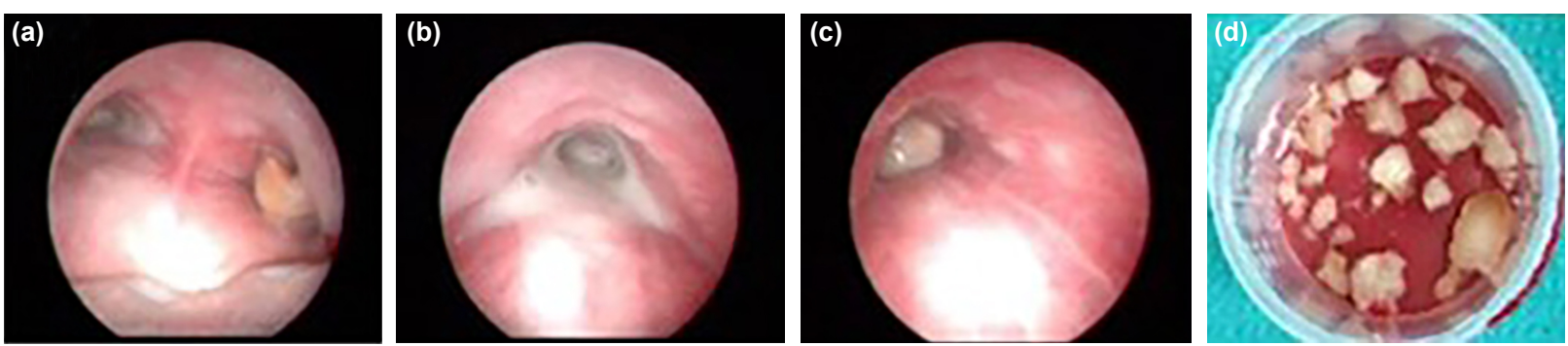

Figure 3. (a-d) A case of foreign body aspiration (pistachio) in both main bronchi.

24 hours after the procedure, and another patient diagnosed with CP died 4 days after the procedure secondary to respiratory failure. Our 30 -day mortality rate was $\% 9$.

Thus 10 (47\%) patients with CAO who had the chance to be operated on survived $(100 \%)$ until they could be operated on by thoracic surgeons.

\section{DISCUSSION}

The SARS-Cov- 2 pandemic required safety measures to be taken in almost all emergency services. ${ }^{\left[{ }^{[9]}\right.}$

Regardless of their specialty the healthcare providers worked in shifts under the provision of chest diseases 
and thoracic surgery and in cooperation with emergency services in our institution. Pulmonology and surgery clinics were rapidly converted to Covid-Clinics, and intensive care units (ICU) to Covid-ICU to meet the increasing number of Covid-19 cases, therefore elective operations were temporarily suspended.

The emergency department during the pandemic predominantly treated patients diagnosed with Covid-19. Meanwhile, patients with life-threatening malignant or BAOs, hemoptysis or previous IBP-related complications either received emergent treatment or were treated shortly after the completion of ancillary examinations. ${ }^{[6,10,11]}$

Five patients $(23.8 \%)$ were categorized to be emergent due to poor general condition, degree of stridor and respiratory failure, and need for immediate intervention. Cases categorized as urgent were either hospitalized or treated in outpatient clinics, provided initial preparations were made so that they could undergo IBP immediately if they deteriorated while awaiting PCR test results before proceeding with IBP ${ }^{[4,10]}$ In their meta-analysis, Reddy et al. ${ }^{[4]}$ summed up the pathway based on the literature to reduce the transmission of the virus and protect those involved. During the first weeks of the pandemic, the absence of symptoms and radiological findings on chest CT were regarded as sufficient to proceed with treatment. In the following weeks, two consecutive negative swab-PCR results were required from the patients according to the newly published guidelines. ${ }^{[5]}$

The main indications for IBP were determined to be CAO, massive hemoptysis, FBA. IBP was administered with similar indications in the pandemic, as seen in our study. ${ }^{[12]}$

Özgül et al. ${ }^{[13]}$ stated that they frequently performed IBP for MAOs, especially for primary pulmonary malignancies, as confirmed by our study. Various complication rates have been reported between different centers, ranging from $0.9 \%$ to $11.7 \%$. While the complication rate was $3.9 \%$ in a study on therapeutic bronchoscopy in MAO, the study of Özgül et al. ${ }^{[13]}$ found the rate of complications to be 7.3\%. IBP were performed on MAO patients, with an acute complication rate of $4.7 \%$. No patients with MAO died during the procedure, and the 30-day early mortality rate was $11.1 \% .^{[14]}$

PITS is known as the most common condition causing BAO likewise our study. Although the rate of CTTS is reported to be $50 \%$ in previous studies, $85 \%$ of our patients were found to have CTTS. ${ }^{[15,16]}$ More interventions are needed because the survival time of BAO patients is expected to be longer. In our series, patients with BAO due to PITS received the highest number of interventions, as did one patient who needed recurrent procedures due to granulation formation. ${ }^{[17]}$ The choice of treatment is known to be surgical resection in patients with CTTS. Before the pandemic period, the initial dilations in patients with PITS were performed in consultation with thoracic surgeons. Since the elective surgeries were postponed in this period, hourglass stents were placed in the same ses- sion to save time in surgery in 2 patients who presented in the first weeks. Following the resumption of operations, one patient with CTTS was referred to surgery after dilation and one patient with web-like stenosis was followed up with bronchoscopy after dilation. ${ }^{[16,18]}$

Rigid bronchoscopy is the preferred procedure for massive or uncontrolled hemoptysis because of its advantage in securing the airway and providing ventilation. ${ }^{[19]}$ In our study, 2 patients with hemoptysis underwent IBP. One of them had CP and the exact bleeding site could not be determined. The second patient had primary lung cancer and hemorrhage was controlled with mechanical resection and APC after the bleeding site was determined. ${ }^{[20]}$

The standard treatment for PAP is WLL performed under general anesthesia and selective intubation. The most common complication of WLL is oxygen desaturation due to possible fluid retention. In our study, 2 sessions of WLL with I week intervals were applied to a patient with respiratory failure due to PAP who was ventilated with non-invasive mechanical ventilation in the intensive care unit. The patient was discharged without the need for oxygen after the second session. ${ }^{[21,22]}$

Various studies in IP report that the overall procedural success rate exceeds $90 \%$, while our success rate is $100 \%{ }^{[23]}$

We had to perform IBP on 10 (47.5\%) patients who, could not be operated on because of the pandemic measures, although they were operable at the time of their admission. These operable patients with life-threatening benign and MAOs were then referred to surgery and operated successfully (100\%). ${ }^{[23]}$

The overall complication rate of IBP was reported between $3.4 \%$ to $13.4 \%$ in some studies, the majority of which were mild and low, and the major complications were rare. ${ }^{[12]}$ Risk factors for complications were urgent and emergent procedures. In our study, the rate of acute complications related to the procedure, such as hemorrhage and arrhythmia, which were controlled during the procedure, was $4.7 \%$, similar to the literature. The rate of chronic complications was $4.7 \%$ (overall complication rate of $8.6 \%$ ) and the 30 -day early mortality rate after 30-day follow-up was $9 \%$, respectively. ${ }^{[2]}$ Apart from the complications directly related to IBP, those related to the implanted stents occupy an important place in IP practice. The most common complications of AS include granulation tissue, migration and mucostasis. One of 3 patients with PITS and stent migration was left to secondary healing and bronchoscopic follow-up, while the stents of the other two were sutured to the trachea to prevent migration recurrence. ${ }^{[16,18]}$

Studies suggested two consecutive negative swab-PCR results prior to bronchoscopic procedures. In the first weeks of the pandemic period, bronchoscopy was performed if there was no clinical signs and if there was no finding compatible with CP in chest CT scans. In the later stages of the pandemic, following the updated suggestions we have also switched to similar apps. ${ }^{[4,5]}$ One patient with 
a clinical diagnosis of CP but negative PCR underwent an emergent procedure for hemoptysis. The patient with PITS that had developed following ICU treatment because of PCR positive CP was found to be negative before our intervention. PCR results of all remaining patients were negative. Two of the PCR-negative patients were hospitalized with PCR-negative CP on the $3^{\text {rd }}$ and $14^{\text {th }}$ days after our intervention. ${ }^{[10,24]}$

We minimized the indications for IBP according to the updated precautions. The operations were carried out in negative pressure units by an experienced team. The number of staff was kept at the required minimum. All team members were trained on how to use personal protective equipments (PPEs). PPEs consists of disposable FFP2 or FFP3 masks, surgical masks, goggles/visors, coveralls with liquid-impermeable hoods, box gowns, bonnets, overshoes, gloves. Patients were donned with disposable box gowns and surgical masks up until the induction of anesthesia, and the entire face was covered with a soaked shield. Filtration valves were added to the ventilator circuit used by the anesthesia team, muscle relaxants were used and manual ventilation was applied. With these precautions taken, no member of our IP team was infected with SARS-Cov-2 (0.0\%). ${ }^{[25]}$

The limitations of our study are its retrospective structure and the small number of patients. However, our study provides information about IBP that cannot be postponed during the peak periods of the ongoing pandemic. It will guide physicians working in this field with real-life data. It also shows that alternative treatments could be available in the absence of surgical interventions.

\section{CONCLUSION}

In emergent/urgent situations, IBP are semi-invasive but considerably safe and efficient methods when precautions, especially PPEs, are taken to protect both the IP team and the patient from infection. It is an effective treatment modality for patients presenting emergently with airway obstruction, massive hemoptysis, and FBA in the current pandemic. It will obviously continue to be used for as long as the pandemic lasts, especially in patients with benign and MAOs, as it saves patients' lives, relieves their symptoms, and saves time until they receive their primary treatment.

Ethics Committee Approval

This study approved by the University Of Health Sciences Hamidiye Scientific Research Ethics Committee (Date: 2 1.08.2020, Decision No: 20/20I).

Informed Consent

Retrospective study.

Peer-review

Internally peer-reviewed.

Authorship Contributions

Concept: E.G.U.C., M.A.O., E.S.; Design: E.G.U.C., D.T., E.S., E.C.; Supervision: M.A.O., E.C.; Fundings: M.A.O.,
E.C.; Materials: E.G.U.C., D.T.; Data: E.G.U.C., D.T.; Analysis: E.G.U.C., E.S.; Literature search: E.G.U.C., E.S., D.T.; Writing: E.G.U.C.; Critical revision: M.A.O., E.S., E.C.

Conflict of Interest

None declared.

\section{REFERENCES}

1. Lu H, Stratton CW, Tang YW. Outbreak of pneumonia of unknown etiology in Wuhan, China: The mystery and the miracle. J Med Virol 2020;92:401-2. [CrossRef]

2. Correia G, Rodrigues L, Gameiro da Silva M, Gonçalves T. Airborne route and bad use of ventilation systems as non-negligible factors in SARS-CoV-2 transmission. Med Hypotheses 2020;141:109781.

3. Ost DE. Bronchoscopy in the Age of COVID-19. J Bronchology Interv Pulmonol 2020;27:160-2. [CrossRef]

4. Reddy PD, Nguyen SA, Deschler D. Bronchoscopy, laryngoscopy, and esophagoscopy during the COVID-19 pandemic. Head Neck 2020;42:1634-7. [CrossRef]

5. Lentz RJ, Colt H. Summarizing societal guidelines regarding bronchoscopy during the COVID-19 pandemic. Respirology 2020;25:574-7. [CrossRef]

6. Hardavella G, George J. Interventional bronchoscopy in the management of thoracic malignancy. Breathe (Sheff) 2015;11:202-12.

7. Davidson K, Shojaee S. Managing massive hemoptysis. Chest 2020;157:77-88. [CrossRef]

8. Wahidi MM, Shojaee S, Lamb CR, Ost D, Maldonado F, Eapen G, et al. The use of bronchoscopy during the coronavirus disease 2019 pandemic: CHEST/AABIP Guideline and Expert Panel Report. Chest 2020;158:1268-81. [CrossRef]

9. Carenzo L, Costantini E, Greco M, Barra FL, Rendiniello V, Mainetti $\mathrm{M}$, et al. Hospital surge capacity in a tertiary emergency referral centre during the COVID-19 outbreak in Italy. Anaesthesia 2020;75:92834. [CrossRef]

10. Seiki H, Yasuji T, Masahiro M, Toshiyuki A, Kenjiro M. Emergency bronchoscopy. Journal of Bronchology1998;5:284-7.

11. Chavez S, Long B, Koyfman A, Liang SY. Coronavirus disease (COVID-19): A primer for emergency physicians. Am J Emerg Med 2021;44:220-9. [CrossRef]

12. Batra H, Yarmus L. Indications and complications of rigid bronchoscopy. Expert Rev Respir Med 2018;12:509-20. [CrossRef]

13. Özgül MA, Çetinkaya E, Turan D, Uğur Chousein EG, Doğan D, Seyhan EC. What have we learned in interventional pulmonology in the past decade? Turk J Med Sci 2019;49:1455-63. [CrossRef]

14. Ost DE, Ernst A, Grosu HB, Lei X, Diaz-Mendoza J, Slade M, et al; AQuIRE Bronchoscopy Registry. Complications following therapeutic bronchoscopy for malignant central airway obstruction: Results of the AQuIRE registry. Chest 2015;148:450-71. [CrossRef]

15. Gelbard A, Francis DO, Sandulache VC, Simmons JC, Donovan DT, Ongkasuwan J. Causes and consequences of adult laryngotracheal stenosis. Laryngoscope 2015;125:1137-43. [CrossRef]

16. Holden VK, Channick CL. Management of benign central airway obstruction. AME Med J 2018;3:76. [CrossRef]

17. Ernst A, Simoff M, Ost D, Goldman Y, Herth FJF. Prospective riskadjusted morbidity and mortality outcome analysis after therapeutic bronchoscopic procedures: results of a multi-institutional outcomes database. Chest 2008;134:514-9. [CrossRef]

18. Huang J, Zhang $Z$, Zhang T. Suture fixation of tracheal stents for the treatment of upper trachea stenosis: a retrospective study. J Cardiothorac Surg 2018;13:111. [CrossRef]

19. Conlan AA, Hurwitz SS. Management of massive haemoptysis with 
the rigid bronchoscope and cold saline lavage. Thorax 1980;35:901-4.

20. Valipour A, Kreuzer A, Koller H, Koessler W, Burghuber OC. Bronchoscopy-guided topical hemostatic tamponade therapy for the management of life-threatening hemoptysis. Chest 2005;127:2113-8.

21. Gay P, Wallaert B, Nowak S, Yserbyt J, Anevlavis S, Hermant C, et al; Groupe d"Endoscopie Thoracique de Langue Française. Efficacy of whole-lung lavage in pulmonary alveolar proteinosis: a multicenter international study of GELF. Respiration 2017;93:198-206. [CrossRef]

22. Chumpathong S, Tscheikuna J, Boonsombat T, Muangman S, Luansritisakul C. Incidence and risk factors of hypoxemia during interventional rigid bronchoscopy under spontaneous-assisted ventilation. J Bronchology Interv Pulmonol 2017;24:268-74. [CrossRef]
23. Ost DE, Ernst A, Grosu HB, Lei X, Diaz-Mendoza J, Slade M, et al; AQuIRE Bronchoscopy Registry. Therapeutic bronchoscopy for malignant central airway obstruction: success rates and impact on dyspnea and quality of life. Chest 2015;147:1282-98. [CrossRef]

24. Luo F, Darwiche K, Singh S, Torrego A, Steinfort DP, Gasparini S, et al. Performing bronchoscopy in times of the COVID-19 pandemic: practice statement from an international expert panel. Respiration 2020;99:417-22. [CrossRef]

25. Herman JA, Urits I, Kaye AD, Urman RD, Viswanath $\mathrm{O}$. COVID-19: Anesthesia Management Recommendations. J Clin Anesth 2020 Apr 23:109840 [Epub ahead of print], doi: 10.1016/j. jclinane.2020.109840. [CrossRef]

\section{COVID-19 Çağında Acil Durumlara Girişimsel Bronkoskopik Yaklaşım}

Amaç: Covid-19 pandemisi sağık alanındaki pekçok işleyişi etkilemiş, bir süre ellektif olan tıbbi ve cerrahi işlemlerin ertelenmesine ya da bulaşıcılığı daha az olan alternatif yöntemlerin kullanılmasına neden olmuştur. Pandemi döneminde yaşamı tehdit eden acil durumlarda girişimsel bronkoskopik işlemler ertelenmeyerek devam etmiştir. Çalışmamızın amacı, girişimsel bronkoskopik işlemleri daha uzun süre dünyayı etkileyecek gibi görünen bu virüsün varlığında, hasta seçimi, aciliyet durumu, işlem başarısı ve komplikasyonları açısından değerlendirmektir.

Gereç ve Yöntem: Covid-I9 hastalı̆ının en yoğun görüldüğü II Mart 2020 ile 0 I Haziran 2020 tarihleri arasındaki ilk dalga sürecinde girişimsel pulmonoloji ünitemizde acil olarak işlem uygulanan 2 I hastanın bilgisayar ve dosya kayıtları retrospektif olarak incelendi.

Bulgular: Çalışmamıza alınan, yaş ortalaması $54.7 \pm 17$ yıl olan 21 hastaya 23 girişimsel bronkoskopik işlem uygulanmıştı. Dokuz hastada malign, dokuz hastada benign hava yolu obstrüksiyonu mevcuttu. Üç hastaya ise hemoptizi ve pulmoner alveolar proteinosise bağlı solunum yetersizliği nedeni ile işlem uygulanmıştı. Multimodalite tedavi olarak uygulanan girişimsel bronkoskopik işlem başarı oranımız \% 100 , akut komplikasyon oranımız \%4.7, kronik komplikasyon oranımız \%4.7, prosedürel mortalitemiz \%0.0 ve 30 günlük erken mortalite oranımız \%9 idi. Tüm işlemler gerekli önlemler alınarak negatif basınçlı girişimsel pulmonoloji ünitesinde yapıldı, ekip üyelerimizden hiçbirinde koronavirüse bağlı herhangi bir belirti ve semptom görülmedi.

Sonuç: Gerekli tüm önlemleri almak kaydı ile pandemi periodunda ortaya çıkan, cerrahi ve invazif girişimlerin uygulanamadığı yaşamı tehdit eden massif hemoptizi, santral hava yolu obstrüksiyonu ve diğer acil durumlarda girişimsel bronkoskopik işlemler yüksek başarı ve düşük komplikasyon oranları ile hastaların hayatını kurtaran, sağkalımı uzatan ve primer tedavilerine kadar onlara zaman kazandıran bir role sahiptir.

Anahtar Sözcükler: Acil; Covid-19; girişimsel pulmonoloji. 